\title{
A REVIEW OF THE LITERATURE ON THEINTEGRATION OF COMPUTER MEDIATED COMMUNICATION (CMC) IN PROCESS WRITING APPROACH TOWARDS ESL STUDENTS' WRITING
}

\author{
Izzah Ismail ${ }^{1}$, Adlina Abdul Samad ${ }^{2}$ \\ ${ }^{1}$ School of Education, Universiti Teknologi Malaysia (UTM), 81310 Skudai, Malaysia \\ ${ }^{2}$ Language Academy, Universiti Teknologi Malaysia (UTM), 81310 Skudai, Malaysia \\ *Corresponding Author Email: izzahismaill@gmail.com, $\underline{\text { m-adlina@utm.mv }}$
}

This is an open access article distributed under the Creative Commons Attribution License, which permits unrestricted use, distribution, and reproduction in any medium, provided the original work is properly cited

\section{ARTICLE DETAILS}

\section{Article History:}

Received 01 March 2019 Accepted 03 April 2019 Available online 08 April 2019

\begin{abstract}
This paper primarily discusses the literature on the asynchronous mode implemented in a Computer Mediated Communication (CMC) environment and process writing approach for writing. The aim of this paper is to develop a research design for the study entitled 'The Role of Computer Mediated Communication (CMC) used in Process Writing Approach among Secondary ESL Students' Writing'. Hence, this review draws on 40 reviewed articles, published from 2006 until 2018. The selected articles were gathered from several online databases such as Google Scholar, Google, Science Direct, ERIC, SAGE, Canadian Center of Science and Education, Taylor \& Francis Online, Mediterranean Journal of Social Sciences, Australasian Journal of Educational Technology, Masters and Doctoral dissertations from researchers all over the world and journal articles from local universities, namely UiTM EJournal, UTM Open E-Journal and UKM Journal Article Repository. Majority of the studies were conducted either in ESL/EFL primary schools, secondary schools or tertiary level settings. The combination of the findings was classified into three sections; idea development and students' engagement; assistance from teachers; apprehension and motivation. The purpose of compiling the data is to discover the connection of incorporating CMC in process writing approach for the enhancement of students' writing skills.
\end{abstract}

\section{KEYWORDS}

CMC, Process Writing, writing skills, ESL secondary school students, asynchronous, apprehension, motivation

\section{INTRODUCTION}

AT Other than speaking, writing can also be regarded as a primary skill in the era of communication. It is one of the common tasks that needs the assistance of our minds to produce sentences and combine them to become comprehensible and meaningful. However, the process of writing in the targeted language becomes complex and complicated due to writers' proficiency levels. According to a study, teaching of writing in English has become a big challenge for majority of ESL/EFL educators [1].

As one of the essential skills that needs to be mastered, apparently, writing requires drills and practices. As declared by a researcher, there are a number of approaches to teach writing used by educators and academicians since decades ago [2]. Before that, traditional method is applied each time during teaching and learning of writing. Most of the time, learners encountered corrections in red pen in their essays and seldom amended their errors. Besides, the method assigns teachers to be the sole source of information while students act as receiver and become the passive. Thus, after several years of language learning, their writing skill remains unsatisfactory.

Through substantial research, several methods and approaches on teaching of writing have been introduced to the ESL/EFL writing settings such as product approach, process approach, genre approach and free approach. A previous scholar highlights that many researchers have specifically emphasized that process approach has been beneficial and functional in writing classroom [3]. Prior to process approach, product approach has been the focused in the classroom. She then defines process approach as a strategy that aims on how the text should be written, rather than focusing on the end product. Another researcher further states that this approach has a significant influence on comprehending "the nature of writing and the way writing is taught" (p. 7) [4]. The approach involves the learners to be fully engaged in the creation of writing pieces. It is produced by implementing methods of writing where multiple drafts of work must be completed by learners. According to research, the goal of this approach is "to make the student aware of, and gain control over, the cognitive strategies involved in writing" (p. 41). It works based on the students' level of needs [5].

A researcher claims that process approach consists of eight stages. The first stage is known as brainstorming [6]. In this stage, students are required to generate ideas by brainstorming through the discussion with peers. The second stage which is the planning stage, focuses on judging the quality of the ideas, presented by the learners in that particular group. Mind mapping which falls under the third stage aims students to organize the thoughts by producing mind map or concept map. It helps students in linking their ideas to develop the structure of their essay writing.

The next stage functions as the first draft of writing. Students should start producing the first draft together with the help of group members. After 
the writing has been completed, they exchange the drafts among other groups. The students are encouraged to give feedbacks about the drafts of other groups. By doing so, it develops the awareness in the readers on how improve or amend the draft created by them. This activity belongs to the fifth stage which is the peer feedback. Editing is regarded as the sixth stage in this approach. Based upon the peer feedback session, the drafts will be returned, and students are required to make amendments of their first drafts. The second last stage is known as the final draft stage. After the amendments are made, the final draft is produced. Teacher's feedback and analysis are the last stage of this approach. Teacher plays a vital role in evaluating the writings and providing a remark regarding the writing.

Today, the system of education in Malaysia has undergone tremendous transformation. Prior to the independence of Malaysia in 1957, the education system followed the policy of British and Japan where teaching and learning was done informally. However, according to a recent scholar, a structured policy was designed and established in education system after 1957 [7]. "The National Philosophy of Education" was then introduced in 1989 "became part of Malaysia's Vision 2020, which its aim was to earn the status of "a fully developed country by the year 2020 " (p.85). In light of the above matter, constructive teaching methods need to be implemented in the education system. Therefore, textbooks are now deemed as obsolete and outdated.

In this day and age, most of the learning tasks are completed via electronic media by which Information and Communication Technology (ICT) has been instituted as the primary mediums of transporting knowledge and collecting information in education setting. As stated by a researcher, technology has improved the way society functions and classrooms needs to go through some changes in order to meet the demand of the $21^{\text {st }}$ century. Moreover, according to research, it is proven that technology integration in classroom is indeed assisting learners in their learning process and create conducive and dynamic environment of teaching and learning [8]. In an attempt to classify Malaysia as a fully developed country by 2020 , the nation has initiated several initiatives to promote the use of technology primarily in the education field.

A study explain that globalisation is the process of transforming the nation into an interconnected world where the two indivisible skills are English and technology [9]. It delivers numerous advantages in providing the students with interesting teaching methods and also helping the teachers to produce remarkable contents in teaching the targeted language [10]. There are several terms used by the researchers to indicate what technology is. According a study, technology is often referred to as "gadgets, instruments, machines and devices". Majority of educators will use the term computer to refer to technology (p. 12) [11]. Other than the terms mentioned above, he then interprets technology as audio visual and media such as videos and slides. Technology is seen to be one of the most effective tools for linguistic and social changes. The focus of technology integration in education system is to upgrade and enhance the "quality, accessibility and cost-efficiency of the delivery of instruction to learners and also to gain positive values from it "to face the challenges of current globalization (p. 175) [12].

A group of researchers express that it is gathered that the keys to enhance language teaching and learning are by the integration of ICT such as Computer-Mediated Communication (CMC), Computer-Assisted Language Learning (CALL) and Mobile-Assisted Language Learning (MALL) [13]. Activities and lessons conducted in the classrooms can be enriched through these remarkable technologies where teachers can get benefits from their numerous functions and significance.CMC provides great exposures opportunities and experiences to educators and learners that cannot be discovered in traditional classes settings. According to research, the central focus of $\mathrm{CMC}$ is the second $\mathrm{C}$ on the acronym which stands for "Communication". Communication can be explained through four principles [14].

\subsection{Communication is Dynamic}

It is a known fact that communication is the connection established by a receiver and a sender through a message. However, in CMC, communication is viewed under the perspective of information processing; the meaning of message does not reside in words but is much more fluid and dependent on the context, shifting constantly from place to place, from person to person and from moment to moment [15].

\subsection{Communication is Transactional}

The focus of communication primarily concerning on negotiation among sender and receiver. The role between listeners and speakers need to switch back and forth to produce authentic communication.

\subsection{Communication is Multifunctional}

It can function as informational (related to content) and (related to relationship between listeners and speakers).

interactional

\subsection{Communication is Multimodal}

As stated by a researcher, it can be elaborated as "meta messages where it is formed by different ways of making meaning (p.18). They are known as communication of non-verbal. Movement and vocal are the examples of how sender and receiver can obtain the message.

M in CMC stands for "mediated" where it can be best described as the process of conveying the message. Finally, the first $\mathrm{C}$ in $\mathrm{CMC}$ is belong to "computer". In other words, CMC can be defined as communication or interaction made by individuals through computer.

According to a group of researchers, there are two types of CMC; synchronous and asynchronous. Synchronous refers to a communication that is happening on actual time where both parties need to be present simultaneously during the discussion [16]. The medium of interaction used in synchronous are chat rooms, instant messaging, video calls and video conferencing such as skype and video calls. Meanwhile, online discussion, email, discussion board, blog, and social networking sites such as Facebook, twitter and YouTube are the examples of the second type of CMC, asynchronous. Based on the medium used to transmit the messages, we can infer that asynchronous can happen at any time, according to both parties' preferences. A researcher believes that asynchronous is the dominant type of CMC since it gives potentially considerable amount of time for both parties to create informative content to discuss on the designated platforms [17].

Many articles and books have been issued and published concerning the integration of CMC used in Process writing approach for teaching and learning of writing. They have discussed and explored a broad range of discussion on the subject matter of thecomparison between CMC and traditional classrooms, the implementation of CMC used in Process writing approach, the importance of CMC in ESL language learning, the effects of CMC in students' writing development and motivation and teachers' and students' perception towards the integration of CMC in writing acquisition. Hence, in an attempt to examine the unexplored issues of these studies for research paper entitled 'The Role of Computer Mediated Communication (CMC) used in Process Writing Approach among Secondary ESL Students' Writing', other than to determine my research design based on this review, I have compiled a document analysis focusing on literature reviews ofProcess writing approach and CMC. The compilations of literature review are presented in the Table 1 and 2.

\section{LITERATURE REVIEW}

This paper collected various published articles that were analyzed manually to determine the research design for the upcoming paper. During the process of selecting the articles, the following keywords were used: 'Process writing approach', 'Computer Mediated Communication', 'writing skills', 'Asynchronous', 'Facebook', 'Technology', 'learners' autonomy, 'collaborative work' and were matched with 'ESL/EFL learners', 'Malaysian education settings', 'perceptions', 'anxiety' and 'motivation'. The selected articles were gathered from several online databases such as Google Scholar, Google, Science Direct, ERIC, SAGE, Canadian Center of Science and Education, Taylor \& Francis Online, Mediterranean Journal of Social Sciences, Australasian Journal of Educational Technology, Masters and Doctoral dissertations from researchers all over the world and journal articles from local universities, namely UiTM E-Journal, UTM Open E-Journal and UKM Journal Article Repository. Majority of the studies were conducted in ESL/EFL primary schools, secondary schools or tertiary level settings and published between the year of 2006 and 2018. Among 40selected articles on CMC and Process writing approach, 19 studies employed quantitative approach, 4studies utilized qualitative, 12 studies used mixed method 
approaches and the remaining 5 were papers with no data.

The findings on the gathered articles are summarized and illustrated in Table 1 and 2 . The tables consist of the summary comprising: $i)$ objectives and purpose of the studies, ii) methodologies and iii) findings. There are 20 relevant articles found for both CMC and Process writing approach. In depth findings will be further discussed in the discussion section.

Table 1: A Review of the Literature on Process Writing Approach

\begin{tabular}{lll}
\hline No & Authors & Objectives/Purpose of the study \\
\hline 1 & Daze \&Ebibi (2014) [17] & - To identify the extent of mean \\
& scores based on learners' writing \\
& achievement through process \\
& writing and traditional method. \\
& -To identify the mean scores of \\
& male and female students based \\
& on their essays conducted via \\
& process writing and traditional \\
& method \\
\hline 2 & - To examine the effects of process \\
& writing in assisting 200 learners \\
& in upper and lower primary \\
& school level to enhance their \\
& writing skills and attitude towards \\
& it.
\end{tabular}

Methodology

Findings

$\begin{array}{ll}\text { - Quantitative research } & \text { - Learners under process writing } \\ \text { design; Quasi Experimental } & \text { scored higher than traditional } \\ \text { - Data Collection: } & \text { method approach. } \\ \text { 1)Pre and Post Tests } & \text {-Process writing boost up their } \\ \text { 2)Essay Writings } & \text { motivation and skills especially if } \\ & \text { the students possessed higher } \\ \text { proficiency of the language. }\end{array}$

- Mixed Method research - Students regarded process writing design as useful in terms of developing

-Data Collection

1) Pre and Post Tests

2)Observation

3)Interviews

4)Questionnaire as useful in terms of developing
ideas and changing their attitudes and habits towards writing (upper primary compared to lower primary).

-benefit advanced level of students more, beginner level might need the assistance from teachers.

\begin{tabular}{lll}
\hline 3 & Alodwan and Ibnian (2014) & $\begin{array}{l}\text { - To investigate the effectiveness } \\
\text { of process approach in developing } \\
\text { tertiary learners' writing skills. }\end{array}$
\end{tabular}

-Quantitative research

design; Quasi Experimental

-Data collection

1)Pre and Post Tests

2)Essay writing

Priting stages have significantly impacted their writing and development.

- Learners produced creative ideas and thoughts as they were only focusing on generating ideas rather than the end product.

\begin{tabular}{llll}
\hline 4 & Wong (2011) [19] & - To explore the perceptions of & -Mixed method research \\
& students and teachers on the design \\
effects of process writing & -Data collection: & \\
& approach in writing acquisition. & 1)Interview & 2)Questionnaire
\end{tabular}
students effects of process writing 2)Questionnaire

Teachers' views -students' work were more comprehensive as they were the main character in the process of writing.
-Teachers need to be the motivator and facilitator for learners who have the difficulties to be on track due to several reasons. Other than that, process writing provides positive impacts in adapting students with the stages to help them write better.

Students' views

-providing examples/guidelines for writing were vital, for them.

-elevate their intrinsic motivation to produce a piece of writing

$5 \quad$ Bayat (2014) [20] $\quad$ - To identify the impacts of success of writing and writing apprehension

-Quantitative research
design;Quasi Experimental
-Data Collection
1)Writing apprehension test
2)Pre and Post Tests
(students' writings)

-the approach has given significant results in reducing students anxiety in writing

-low chance of unsuccessful of producing the end product of essays -work were evaluated for several times were the main reasons that process writing approach was a success

Dockchandra (2018) [21]

-Quantitative research design. -Data Collection:

1)Pre and Post Test (students writings)

2)Questionnaire
-Learners improvement in their writing were influenced by the collaborative learning embedded indirectly in process writing approach - discussion, designing the essay together which led to better comprehension towards the topic discussed.

-Teachers feedback may be the obvious results of students' improvement as they received on the spot feedbacks from teachers, face to face, right before they submitted their work - ample of time to amend their work.

\begin{tabular}{|c|c|c|c|c|}
\hline & & & & 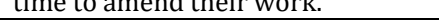 \\
\hline 7 & Akinwamide (2012) [22] & $\begin{array}{l}\text { - To examine how process writing } \\
\text { approach can influence ESL } \\
\text { learners' performance in writing } \\
\text { acquisition. }\end{array}$ & $\begin{array}{l}\text {-Quantitative research } \\
\text { design; Quasi Experimental } \\
\text {-Data Collection }\end{array}$ & $\begin{array}{l}\text { - editing stage played an important } \\
\text { role in writing performance of the } \\
\text { students. They get to spend more }\end{array}$ \\
\hline
\end{tabular}


1)Pre and Post Tests (learners essay writings) time to think and analyze their work and collecting more ideas. -process approach led the students to be in learners' autonomous environment.

8 Sheir, Zahran\& Koura (2015) - To investigate the effectiveness [23] of process writing in enhancing the writing skills of Engineering students'.

9

Diliduzgun (2013) [24]

- To examine the impacts of process approach among teachers as well as provide them with

writing approach to be implemented in class

(a)

-Quantitative research -stages in process writing assisted design; Quasi Experimental students to repeatedly practicing -Data Collection: (students' essays)

their writing and avoid producing errors.

-process approach focused on the 1)Pre and Post Tests wording and grammar. Hence, students can overcome the problems that curb them from producing well written essays

-Mixed Method research -students steer away from
design unnecessary repetition in essays -Data Collection:

1)Pre and Post Tests (essay writings)

2)Questionnaire (analyzed qualitatively) and managed to produce essays that flows smoothly.

-Writing is a form of exercise and process writing is the effective method to be executed in the process of writing instead of classroom with the assistance from teachers to guide the students throughout the lesson

\begin{tabular}{|c|c|c|}
\hline Ozen (2016) [25] & $\begin{array}{l}\text { To what extent does process } \\
\text { writing give impact towards the } \\
\text { achievement and attitude of pre } \\
\text { service teachers }\end{array}$ & $\begin{array}{l}\text {-Mixed Method research } \\
\text { design } \\
\text {-Data collection: } \\
\text { 1)Pre and Post Tests (essay } \\
\text { writings) } \\
\text { 2)Structured interviews. }\end{array}$ \\
\hline
\end{tabular}

-active participation and engagement during the classes were conducted. They explored their writing ability rather than focusing on taking notes and focusing on grammatical errors. -implementation of process approach driven the participants to produce a better written essays and remarkable insights

$\begin{array}{ll}11 \text { Puengpipattrakul (2014) [26] } & \text { - To investigate whether process } \\ & \text { writing assist the first year } \\ & \text { students of Thai Sport Science to } \\ & \text { establish socio-cognitive skills. }\end{array}$

-Mixed Method research -Process writing exposed students design to write systematically.

-Data Collection: -Without teachers' assistance, mot 1)Writing tasks groups failed to initiate 2)Semi-structured interview conversation probably due to shyness and low self-esteem.

-Teachers should analyze students' background before come out with an activity. "Personal experience" essay may not be suitable as students were from different background

$12 \quad$ Mehr (2017) [1] $\quad$-To discover the effect of process
and product approach towards the learners attitudes on writing

-Quantitative research
design; Quasi Experimental
-Data Collection:
Pre and Post Tests (E-
Process, C- Product)
1)Essay writings
2)Preliminary test (prior to
the study)

approach group outperformed Product group in terms of ideas development, fluency and the usage of discourse markers. -students in process learning the process of writing step by step rather than focusing on the whole essay on its own.

-Process writing were distinguished into certain parts and that aid students to have a clearer view on the written essay.

\begin{tabular}{|c|c|c|}
\hline $13 \quad$ Souhila (2014) [27] & $\begin{array}{l}\text { - To determine the role of process } \\
\text { writing in improving students' } \\
\text { writing }\end{array}$ & $\begin{array}{l}\text {-Mixed method } \\
\text {-Data collection: } \\
\text { 1)observation } \\
\text { 2)Questionnaire for teachers }\end{array}$ \\
\hline
\end{tabular}

-positive responds towards the tasks given as students were discussing; sharing thought and insights with each other while completing the stages of process approach.

-Teachers prefer to implement process approach rather than other approaches because it brings the best out of the students

\section{Pour-Mohammadi,} ZainolAbidin \& Cheong (2012) [28] -discuss the impacts of process writing on the quality of writing of three form one students in Malaysia

-Mixed method research
design
1)Writing essays
2)Observation
2)semi-structured interview
-help from teachers especially clear and precise instruction before they started off with the essays influenced them a lot in generating ideas and produce smooth flow writing piece.

-writing quality varied from the pre-test. Notice that even though high level of proficiency students can finish the pretest with flying 


\section{5}

Johari (2018) [29]

16

Rohmatika (2014) [30]
- To investigate the effectiveness of task based process writing approach towards the academic writing performance of ESL undergraduates learners.
-Mixed Method

-Data collection:

1)Pre and Post Tests

(paragraph writing for pre test)

2)group portfolios

3)questionnaires

4)students'

(measured qualitatively)

-Quantitative

design; factorial.

-Data collection:

1)writing tests approach in teaching of writing among eighth grade learners in SMP TerpaduPonorogo

reflection
vely) 2)test of verbal creativity colors, that does not mean they can ace the writing process journey. -language competence is important in process writing environment. -Findings showed students composed better organization and content when task based process writing approach was involved. -Task based process approached also improved learners' quality of academic writing and vocabulary skills, significantly.

-Learners in process writing group produced well written text as the approach was flexible on the ideas and how to students wanted the essays to be.

-Effectiveness of teaching approaches were depending on learners' creativity and skill and process approach served the purpose as compared to product approach.

17 Onazawa (2010) [3] - focus on benefits, downfalls of
process approach explore the topics discussed through writing and it increased the intrinsic motivation of the students

-the approaches focuses on the different kind of classroom activities.

-less attention on structure and grammar accuracy matter, together with the end product.

$18 \quad$ Alhosani (2008) [31]

\begin{abstract}
- To discover the role of ESL teachers during the
implementation of process writing approach in classroom to five ESL fifth grade learners in Saudi Arabia.

-To know the importance of process writing approach on writing performance of those students.
\end{abstract}

-Qualitative research design; case study -Data collection:

1) interview with teachers and participants

2)observation in class

3)think aloud protocols

4)students' classroom -role of teachers

1)inspire students to write

2)exchange real life experience to promote writing

3)provide comments and feedbacks to students

-significance of process writing

1) For young learners, process approach encouraged learners to read aloud the written text which simultaneously can develop their other integrated skills literacy.

\begin{tabular}{|c|c|c|c|}
\hline 19 & Badiaa (2016) [32] & $\begin{array}{l}\text {-To examine the effects of process } \\
\text { writing on learners' writing } \\
\text { performance }\end{array}$ & $\begin{array}{l}\text {-Quantitative research design } \\
\text {-Data collection: } \\
\text { 1)Questionnaire }\end{array}$ \\
\hline
\end{tabular}

$20 \quad$ Boas (2011) [33]

- To prove how important process approach in writing classroom environment

- Process approach play an vital and positive roles in developing students ability to write.

-the approach consists of several tasks which promote learners' proficiency and capacity.

- The process of this approach begins from exploring students' writing process through the stages in this approach and ends at checking the end results.

- Students' creativity, motivation, interest and cognitive skills were emphasized during this approach being executed.

- Initially started in L1 classroom environment and gradually established in ESL/EFL school settings environment

Table 2: A Review of the Literature on Computer Mediated Communication (CMC)

\begin{tabular}{|c|c|c|c|c|}
\hline No & Authors & $\begin{array}{l}\text { Objectives/Purpose of the } \\
\text { study }\end{array}$ & Methodology & Findings \\
\hline 1 & $\begin{array}{l}\text { Perea } \quad(2015) \\
{[14]}\end{array}$ & $\begin{array}{l}\text { - To provide tasks and suitable } \\
\text { material for formal writing } \\
\text { lessons. }\end{array}$ & $\begin{array}{l}\text {-Qualitative research } \\
\text { design } \\
\text {-Data Collection } \\
\text { 1)Online Survey } \\
\text { 2)Questionnaire } \\
\text { 3)Face to Face discussion }\end{array}$ & $\begin{array}{l}\text { - Instilled positive attitudes as they were given a chance } \\
\text { to publish their works, online. }\end{array}$ \\
\hline
\end{tabular}


2 Omar, Embi \& - To explore the participation Yunus (2012) of students in an online task [34] conducted through Facebook. - To find out the benefits of information sharing task on Facebook among university level students.

3 Hussin, $\quad-$ To explore the role of CMC Abdullah, Ismail integration on ESL/EFL \& Yoke (2015) writing apprehension. [35]
-Quantitative

design

-Data Collection

1)Facebook postings

2)Summary

3)Questionnaire

-Mixed Method research

design

-Data Collection

1)Interview

2)Observation

3)Second Language Writing Anxiety Inventory (SLWAI)

$4 \quad$ Allam \& Elyas - To identify teachers (2016) [36] perceptions on implementing social media at tertiary level

- To investigate the obstacles in utilizing the tools.

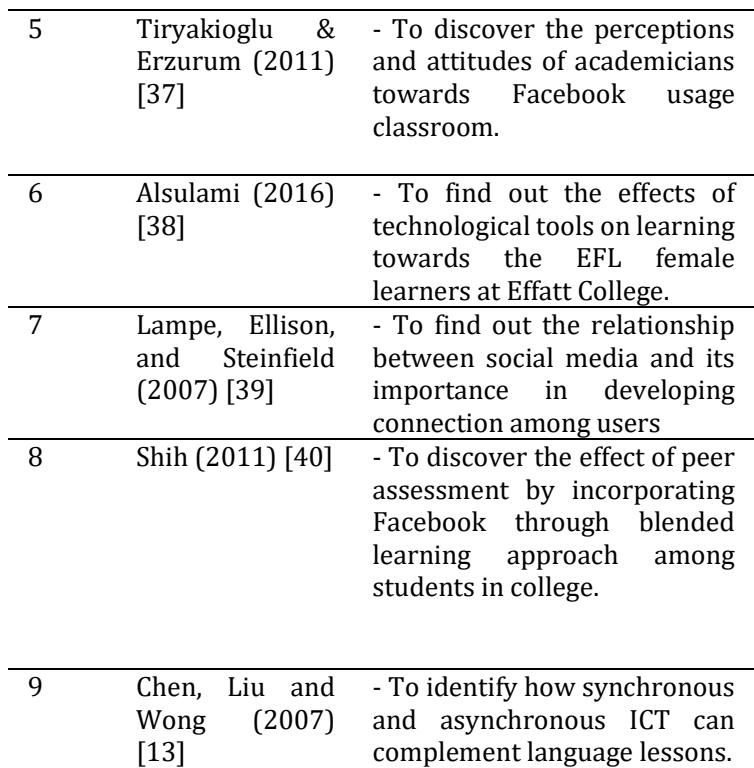

-Quantitative research

design

-Data collection:

1)Survey

2)Online questionnaire

-Quantitative

design

-Data Collection:

1)Survey

-Quantitative

design

-Data Collection

1)Electronic questionnaire

-Quantitative research

design

-Data Collection;

1)Questionnaire

-Mixed Method research

design

-Data collection

1)Pre and Post Tests

2) Survey Questionnaire

3)Self Reflection

4) interviews

\section{complement language lessons.}

(1)

-Students were eager to complete the task despite language barriers and some technical issues. -Asynchronous
1) Students felt like they were having a discussion face to
face even though it was a virtual one.

2) May cause students to become unnatural due to the camera and video recorder exposure.

- Asynchronous

1) Trained learners to be more independent as the tasks become more flexible and can be done outside of the classroom.

2) Encouraged learners to search for additional information.

\begin{tabular}{|c|c|c|c|c|}
\hline 10 & $\begin{array}{l}\text { Maesin, Mansor, } \\
\text { Shafie rand } \\
\text { Nayan (2009) } \\
{[41]}\end{array}$ & $\begin{array}{l}\text { - to examine tertiary level } \\
\text { students' preference for tasks } \\
\text { of collaborative learning in } \\
\text { English classes. }\end{array}$ & $\begin{array}{ll}\text {-Quantitative } & \text { research } \\
\text { design } & \\
\text {-Data Collection } \\
\text { 1)Survey } \\
\text { 2)Interview }\end{array}$ & $\begin{array}{l}\text { - Digital learning environment allows learners to be in an } \\
\text { ideal atmosphere that supports them to acquire } \\
\text { knowledge autonomously and collaboratively despite } \\
\text { their different styles of learning. }\end{array}$ \\
\hline 11 & $\begin{array}{l}\text { Foroutan, } \\
\text { Nordin and } \\
\text { Hamzah (2013) } \\
{[42]}\end{array}$ & $\begin{array}{l}\text { - To find out the significance of } \\
\text { weblog in assisting } \\
\text { autonomous in writing }\end{array}$ & $\begin{array}{l}\text {-Mixed Method research } \\
\text { design } \\
\text {-Data collection } \\
\text { 1)Survey } \\
\text { 2)Blog entries } \\
\text { 3)Interview } \\
\text { 4) Observation } \\
\end{array}$ & $\begin{array}{l}\text {-Weblog was proven to be powerful tool for students to } \\
\text { express their thoughts and ideas collaboratively. } \\
\text {-Students were the suppliers of knowledge during the } \\
\text { lesson as teachers acted as facilitator - learner centered } \\
\text { class. }\end{array}$ \\
\hline 12 & $\begin{array}{l}\text { Krasnova and } \\
\text { Ananjev (2015) } \\
{[43]}\end{array}$ & $\begin{array}{l}\text { - To illustrate learners' } \\
\text { perception and experiences } \\
\text { towards online discussions via } \\
\text { interviews and questionnaire. }\end{array}$ & $\begin{array}{l}\text {-Qualitative research } \\
\text { design } \\
\text {-Data Collection } \\
\text { 1)Interviews } \\
\text { 2)Questionnaire } \\
\text { 3)Peer assessment } \\
\text { 4)Forum entries } \\
\end{array}$ & $\begin{array}{l}\text {-Online activities offered engaging and inspiring activities } \\
\text { for students. It expands students mind and students have } \\
\text { the chance to gain more knowledge. } \\
\text {-It also gave the opportunity to collaborate, reflect and } \\
\text { interact with peers }\end{array}$ \\
\hline 13 & $\begin{array}{ll}\text { Daniel } \\
\text { [44] }\end{array}$ & $\begin{array}{l}\text { - To find out the importance of } \\
\text { online learning }\end{array}$ & & -Online learning nurtured proactivity in students. \\
\hline 14 & $\begin{array}{l}\text { Shooshtaria and } \\
\text { Mir (2014) [45] }\end{array}$ & $\begin{array}{l}\text {-To examine how scaffolding } \\
\text { helps in enhancing ESL } \\
\text { students' writing procedures } \\
\text { and performance with the } \\
\text { assistance of peers and } \\
\text { random feedback from } \\
\text { instructor. }\end{array}$ & $\begin{array}{l}\text {-Quantitative research } \\
\text { design } \\
\text {-Data Collection } \\
\text { 1)Pre and Post Tests } \\
\text { 2)Essay writings } \\
\text { 3)Voice recording related } \\
\text { to essays }\end{array}$ & $\begin{array}{l}\text {-Scaffolding transforms teacher centered learning to } \\
\text { student centered learning. }\end{array}$ \\
\hline
\end{tabular}


15 Sakkir, Rahman - To discovers learners' views \&Salija (2016) on the role of social media [46] during the process of teaching in STKIP, South Sulawesi, Indonesia.
Mixed Method research design -Data collection;

1)Three - analyze quantitatively qualitatively
-Students have the access to search for additional information regarding the topics discussed

- However most of the time the school (rural) has a very limited internet access hence unable the students to complete their work within the time range given.

\begin{tabular}{|c|c|c|c|c|}
\hline 16 & (2011) & $\begin{array}{l}\text { - Integration of Process } \\
\text { Writing and Social Media and } \\
\text { Blog }\end{array}$ & & $\begin{array}{l}\text { - illustrates on how social network and blog provide } \\
\text { wider opportunities for learners to perform better during } \\
\text { the stages of process writing. } \\
\text { - help learners to broaden their digital literacy. }\end{array}$ \\
\hline 17 & $\begin{array}{l}\text { Mbodila } \\
\text { Ndebele } \\
\text { Muhandji } \\
\text { (2014) [47] }\end{array}$ & $\begin{array}{l}\text { - To determine the effects of } \\
\text { social media on learners' } \\
\text { acquisition focusing on } \\
\text { learners' collaboration and } \\
\text { engagement via Facebook. }\end{array}$ & $\begin{array}{l}\text { - Quantitative research } \\
\text { design } \\
\text { - Data Collection } \\
\text { 1)Questionnaire - semi } \\
\text { structured questions } \\
\text { 2) Opinion statements } \\
\end{array}$ & $\begin{array}{l}\text { - The use of Facebook has significantly impacted students' } \\
\text { engagement and collaboration with peers. } \\
\text { - Facebook classroom transcends traditional classroom }\end{array}$ \\
\hline 18 & $\begin{array}{l}\text { Majid, Stapa and } \\
\text { Keong (2015) } \\
{[48]}\end{array}$ & $\begin{array}{l}\text { - To discover the view of ESL } \\
\text { learners towards the use of } \\
\text { blended scaffolding via } \\
\text { Facebook in enhancing } \\
\text { students' writing steps and } \\
\text { performance. }\end{array}$ & $\begin{array}{l}\text { - Quantitative } \\
\text { - Data Collection } \\
\text { 1)Essay writings } \\
\text { 2)Facebook posts }\end{array}$ & $\begin{array}{l}\text { - Through scaffolding, certain part of the tasks are carried } \\
\text { out with assistance, by the individual according to their } \\
\text { ability while the rest are scaffolded by the adults. }\end{array}$ \\
\hline 19 & $\begin{array}{l}\text { Noriah \& Intan } \\
\text { (2012) [49] }\end{array}$ & $\begin{array}{l}\text { - To investigate how Selected } \\
\text { Online Writing Links and } \\
\text { Resources (SOWLR) influence } \\
\text { learners' interest and } \\
\text { engagement on producing } \\
\text { essays. }\end{array}$ & $\begin{array}{l}\text { - Quantitative research } \\
\text { design } \\
\text { - Data Collection } \\
\text { 1)Pre and } \\
\text { Questionnaires } \\
\text { 2) Essay writings } \\
\text { 3) Survey questionnaire } \\
\text { (prior to the study) }\end{array}$ & $\begin{array}{l}\text { - SOWLR enhanced students' interest and enthusiasm in } \\
\text { producing a good essay. } \\
\text { - Changed learners' negative attitudes towards writing by } \\
\text { issuing interesting and effective online writing resources. }\end{array}$ \\
\hline 20 & $\begin{array}{ll}\text { Endoo } & (2015) \\
{[50]} & \end{array}$ & $\begin{array}{l}\text { - To discover the relationship } \\
\text { between FB integration and } \\
\text { attitudes with the } \\
\text { development of writing skills }\end{array}$ & $\begin{array}{l}\text {-Qualitative research } \\
\text { design }\end{array}$ & $\begin{array}{l}\text {-Other than students managed to improve their writing } \\
\text { skills/style, they were also managed to learn new } \\
\text { vocabulary through Facebook. }\end{array}$ \\
\hline
\end{tabular}
among the first year students at Surin Campus.

\section{RESULTS AND DISCUSSIONS}

Based on these reviews of literature, there are numerous findings that can be found from the 40 published articles related to Process Writing approach and Computer Mediated Communication in Tables 1 and 2. In order to analyze the data from the 20 reviewed articles on Process Writing approach in Table 1, the keywords used were: 'process approach', 'writing skills', 'effects', 'role' and 'impacts' and were combined with 'traditional method', 'attitudes', 'writing acquisition', 'writing apprehension', 'ESL learners' and 'writing performance' while for the gathered articles on CMC in Table 2, the keywords used were: 'effectiveness of CMC', 'technology', 'social media', 'Facebook' and 'asynchronous' and were matched with 'schools setting', 'learners' autonomy', 'participation', 'apprehension', 'motivation' and 'tertiary level'. As a result, the overall findings were tabulated into three categories: idea development and students' engagement; assistance from teachers; apprehension and motivation. The process of tabulating the findings were based on the objectives and purposes as well as the findings of the studies.

\subsection{Idea Development and Students' Engagement}

The findings were analyzed according on how the implementation of CMC in Process writing approach can enhance students' writing development and engagement through the activities conducted in the stages of Process writing. This section will focus on the students' engagement and idea development by students' as analyzed in most of the selected articles. A researcher then highlights that with the integration of Process writing in writing classrooms, more learners begin to plan, revise and edit their drafts before they start composing them into an essay. As supported by another previous researcher, the pre-writing stages; brainstorming, planning and mind mapping foster learners to connect, generate and construct new ideas and contents that highly influenced their ways and flow of writing. Other than that, while-writing and post-writing stages that consist of editing, first draft, peers and teacher feedbacks, final drafts as well as publishing equipped them with remarkable insights to enhance their writing organization, learning from errors produced during the first draft.
In addition, a researcher reports that Process Writing approach has positively impacted students' socio-cognitive skills through the brainstorming stages up to the editing stages as they are required to practice their writing. In order to do so, learners need to collaborate with their peers to interact and share their ideas based on their own experiences or additional information that they encountered. This is one of the effective ways to convey their thoughts in writing. Furthermore, with the implementation of collaborative group work, learners acquire a better comprehension regarding the topic discussed. It allows learners to give and receive feedbacks from peers regarding their contributions during the discussion and writing activities. The comments they received might help them in honing their ways of thinking and collaborating with their peers. A researcher believes that students' improvement in their writing performance and socio-cognitive skills are affected by the collaboration work which constantly being incorporated in Process Writing approach.

In helping learners to enhance the mentioned skills, technology too, plays an essential role in this approach. Besides, technology helps in maximizing the exposure of English which will benefit the students in achieving the aims of the Process Approach. Based on the studies, it is proven that the integration of CMC help in transforming learners to become active and engaged throughout the lessons. According to a group of researchers, CMC instilled positives attitudes in students towards writing as the students used the tools on a daily basis. With the implementation of Social Networking Sites (SNS) in writing classroom, students demonstrate eagerness towards their published work on SNS and develop personal growth and development.

As defined by a researcher, Social Networking Sites (SNS) is "a unique online service, platform, or area where social communication and/or social relations can be established, and individuals intensely share information (p. 135). They then elaborate that Facebook, one of the SNS means that promotes interaction and creates chances for finding additional information, developing interest and allowing information sharing opportunities for more information, interest, and data sharing. Not only SNS are good for students writing skills progression, it also has the potential to foster and develop the learners' interest in learning English as well as broaden their digital literacy. This is because, learners find SNS and 
technology devices as beneficial, extremely entertaining and user friendly. In addition, a researcher states that by stimulating learners' engagement with SNS, they can establish connections and rapport with their classmates.

As stressed by a previous scholar, Facebook also functions as a platform to scaffold and organize students' ideas and thoughts as well as interest to be shared with other users. Correspondingly, a scholar emphasizes that Facebook encourages learners to communicate and collaborate. Through several popular features of Facebook such as comments, private message, group chat room, like, friends and notifications, students are motivated to participate and engage in the discussion created to complete certain tasks. They can use these features to express and share their ideas and insights as well as giving feedbacks and comments during peer feedback stage. A study report that digital learning environment allows learners to be in an ideal atmosphere that supports them to acquire knowledge autonomously and collaboratively despite their different styles of learning. Furthermore, with the existence of $\mathrm{CMC}$ in the classroom, learners are able to search own materials and additional information pertaining to the topic of discussion which is beneficial for the pre-writing stage of Process writing approach. Moreover, the integration of CMC in Process writing is proven to be an effective way "to nurture proactivity, a useful trait in the workplace.

Other than that, activities conducted through CMC can facilitate learners writing progress as they can visit the sites numerous times, for revision purposes. They can always draft, edit and resubmit their writing until they are satisfied with their quality of work. These beneficial opportunities might curb the worrisome matters faced by learners especially in their writing activities. Moreover, learner autonomy in language learning is the result of the flexibility in choosing the time, place and materials.

\subsection{Role of Teachers in CMC and Process Writing Approach in Writing Classrooms}

This section comprises of the role of educators in CMC and Process writing approach classroom environment. Over the past years, classrooms were dominated by teachers. Teacher-centered learning were implemented where educators acted as a sole leader, giving students all the insights and information throughout the lessons and depending on extrinsic motivation to influence learners attitudes towards teaching and learning. However, over the last decade, education system has shifted from teacher-centered learning to student-centered learning. Findings on numerous studies shown that student-centered learning executed numerous benefits towards learners as compared to teacher-centered learning. In the recent years, teachers' role has switched from sole provider to facilitator, scaffolder and motivator in the classroom. According to a study, scaffolding is a gradual withdrawal of adult (e.g., teacher) support through modelling, questioning, instruction and feedback for a student's performance "across successive engagements, thus transferring more autonomy to the child" ( $p$. 1771).

In addition, a researcher points out that scaffolding is a process of aiding a person to conduct a task that is challenging or unfamiliar for her/his ability. Through the process, certain part of the tasks are carried out with assistance, by the individual according to their ability while the rest are scaffolded by the adults. Another researcher explains that assistance from educators in writing classroom has tremendously increased learners' engagement and attitudes towards writing. For instance, a research explores that in developing the learners' interest in writing, teacher should possess the role of inspiring the students that writing is an interesting task [51]. Before engaging themselves in the brainstorming activity, teacher may instruct the students to watch a short video regarding the related topic of the week and ask the students to jot down the main points of the video.

A recent scholar adds that in incorporating the method in the classroom, educators should create or provide meaningful tasks and interesting activities that [52]:

Boost their motivation level and take their interest and knowledge level as well as proficiency level into account.

Simplify the activity especially the instruction "to make it more manageable and achievable" for the learners (p.3).
Provide guidance and assistance for the students to obtain the next level of development.

Lessen the risk of feeling demotivated and frustrated of not being able to carry out the tasks with or without the assistance of teachers.

\subsection{Apprehension and Motivation}

The findings on this section focuses on how CMC in Process writing approach conducted in class can affect students' anxiety and motivation levels. A researcher highlights that this approach is effective in decreasing students' anxiety because the drafts produced need to be analyzed a few times by teacher, their peers and even themselves. It also influences the level of motivation and self-confidence in students as they believe they are on a par with other students. The completed piece of writing will contain limited errors. Furthermore, practical activities with the integration of CMC in process writing stages such as brainstorming and mind mapping; students are required to discuss with peers and relate their previous knowledge in the discussion and evaluating their work during feedback and editing stages may lead to low level of anxiety and high level of motivation since students can avoid giving comments face to face and reduce their shyness passive attitudes towards the activities. As studied by a researcher, the integration of CMC inprocesswriting approach in lessons lessen the percentage of negative perceptions about writing. Another researcher believes that drilling students to follow the steps of process approach could assists learners to overcome their writing incompetence. This is supported by a researcher who state that accommodating learners with such exposure could furnish to mould the ability to apply basic skill in writing and developing self-regulatory skills. With the incorporation of process approach in writing lesson, the worrisome level of anxiety, motivation and self-confidence can be alleviated.

\section{CONCLUSION}

From the overall findings of the review, it was clearly stated that the integration of CMC in process writing approach hone students' writing skills. The studies have displayed how CMC can be beneficial in developing ideas and improving students writing through process writing approach, transforming teacher dominated teaching and learning into learners dominated classroom and decreasing their level of anxiety and simultaneously elevate their motivation and confidence level. As a result of this review, I am going to further explore the undiscussed issues related to the studies, for my research paper. Other than that, the 40 gathered articles have given me insights and exposure on how I am going to develop my research design, conduct my research study, collect the data and adopt suitable and appropriate instruments for my study. Extensive readings related to CMC and process writing approach in writing environments will be done in order to meet the objectives of the research paper.

\section{REFERENCES}

[1] Mehr, H.S. 2017. The impact of product approach and process approach on Iranian EFL learners' writing ability and their attitudes towards writing skill. International Journal of English Linguistics, 7(2), 158-166.

[2] Rusinovci, X. 2015. Teaching Writing through Process-Genre Based Approach. US-China Education Review A, 5(10), 699-705.

[3] Onozawa, C. 2010. A study of the process writing approach. (A suggestion for an eclectic writing approach). Retrieved from: http://www.kyoai.ac.jp/college/ronshuu/no-10/onazawa2.pdf

[4] Al-Khasawneh, F.M. 2010. Writing for academic purposes: Problems faced by Arab postgraduate students of the college of business, UUM. ESP World, 9(2), 1-23.

[5] Nemouchi, A. 2014. Approaches to teaching writing.

[6] Steele, V. 2004. Product and process writing. Retrieved on 5th Sept. 2010 from http://www.englishonline.org.cn/en/teachers/workshops/teachingwriting/teaching-tips/product-process 
[7] Grapragasem, S., Krishnan, A., Mansor, A.N. 2014. Current trends in Malaysian higher education and the effect on education policy and practice: An overview Current Trends in Malaysian Higher Education and the Effect on Education Policy and Practice: An Overview. International Journal of Higher Education, 3(1), 85-93.

[8] Hassan, S. 2009. Integrating ICT in teaching and learning: Country report: Malaysia. Retrieved from: http://woulibrary.wou.edu.my/weko/eed502/Shamsuddin_ICT_in_Mala ysia_Education.pdf

[9] Tsui, A., Tollefson, T. 2007. Language Policy and the Construction of National Cultural Identity. In Tsui, A \&Tollefson, J (Eds), Language Policy, Culture and Identity in Asian Contexts (1-21). Mahwah, NJ: Lawrence Erlbaum.

[10] Shyamlee, S.D., Phil, M. 2012. Use of technology in English language teaching and learning: An analysis. Retrieved from: http://www.ipedu.com/vol33/030/- ICLMC2012LI0042.pdf.

[11] King. G.C. 2002. Teachers' use of technology in the teaching and learning of English language in urban and rural schools. A comparative survey. Retrieved from: goh\%252Bchui\%252Bking.pdf

[12] Ghavifekr, S., Rosdy, W.A.W. 2015. Teaching and learning with technology: Effectiveness of ICT integration in schools. International Journal of Research in Education and Science (IJRES), 1(2), 175-191.

[13] Chen, Y., Liu, C.H., Wong, R. 2007. The adoption of synchronous and asynchronous media in the teaching of a second language. Issues in Information Systems, 8(1), 217-223.

[14] Perea, S. 2015. Communicative writing: Integrating computer mediated communication in the ESL classroom. Retrieved from: https://linguistics.uoregon.edu/wpcontent/uploads/2015/09/PereaShawn-Aug-15.pdf

[15] Thurlow, C., Lengel, L., Tomic, A. 2004. Computer Mediated Communication. London: SAGE Publication.

[16] Kaur, R., Sidhu, G.K. 2010. Learner autonomy via asynchronous online interactions: A Malaysian perspective. International Journal of Education and Development using Information and Communication Technology (IJEDICT), 6(3), 88-100.

[17] Romiszowski, A., Mason, R. 2004. Computer-mediated communication. In D. H. Jonassen (Ed.), Handbook of research on educational communications and technology (pp. 397-432). Mahwah, New Jersey: Lawrence Erlbaum Inc.

[18] Alodwan, T.A., Ibnian, S.S. 2014. The effect of using process approach to writing on developing university students' essay writing skills in EFL. Review of Arts and Humanities, 3(2), 139-155.

[19] Wong, B.L. 2011. An investigation of the process writing approach as a curriculum innovation in local junior secondary classrooms: Three case studies1. (Thesis). University of Hong Kong, Pokfulam, Hong Kong SAR. Retrieved from http://dx.doi.org/10.5353/th_b4836916

[20] Bayat, N. 2014. The effect of the process writing approach on writing success and anxiety. Educational Sciences: Theory \& Practice, 14(3), 11331141, doi: 10.12738/estp.2014.3.1720.

[21] Dockchandra, D. 2018. The effects of process writing approach on performance of an overcrowded EFL writing class at a University of Thailand. Paper presented at The 1st Annual International Conference on Language and Literature, KnE Social Sciences, Kasetsart University, Thailand.

[22] Akinwamide, T.K. 2012. The influence of process approach on English as second language students' performance in essay writing. Canadian Center of Science and Education, 5(3), 16-29.

[23] Sheir, A.A., Zahran, F.A., Koura, A.A. 2015. The effectiveness of process writing approach in developing EFL writing performance of ESP college

students.

Retrieved

from:

http://search.shamaa.org/PDF/Articles/EGJes/JesVol23No3P1Y2015/je s_2015- v23-n3-p1_001-023_eng.pdf

[24] Diliduzgun, S. 2013. The effect of process writing activities on the writing skills of prospective Turkish teachers. Eurasian Journal of Educational Research, 52, 189- 210.

[25] Ozen, E.G. 2016. The effect of process oriented writing activities on the achievement and attitude of the pre-service primary school teachers: An example of mixed method study. Journal of Education and Training Studies, 4(11), 227-237.

[26] Puengpipattrakul, W. 2014. A process approach to writing to develop Thai EFL students' socio-cognitive skills. Electronic Journal of Foreign Language Teaching, 11(2), 270-284

[27] Souhila, D. 2014. Developing EFL writing skill through the use of process approach: A case study of second year students at Mohammed Kheider University of Biskra. Retrieved from: http://dspace.univbiskra.dz:8080/jspui/bitstream/123456789/6016/1/Djidel\%20Souhila. pdf

[28] Pour-Mohammadi, M., ZainolAbidin, M.J., Cheong, L.F. 2012. The effect of process writing on the quality of form one students: A case study. Canadian Center of Science and Education, 8(3), 88-99.

[29] Johari, S.K. 2018. The effects of Task-Based process writing approach on the academic skills among second language tertiary learners. Journal of ELT Research, 3(1), 1-20.

[30] Rohmatika, A. 2014. The effectiveness of process approach in teaching writing viewed from students' level of creativity and its implaction towards writing assessment. Retrieved from: https://core.ac.uk/download/pdf/43024972.pdf

[31] Alhosani, N.M. 2008. Utilizing the writing process approach with English as a second language writers: A case study of five fifth grade ESL Arab students. Manhattan, Kan: Kansas State University.

[32] Badiaa, A. 2016. The role of the process approach to improve EFL learners writing skill: The case of first year master students of English at Biskra University. Retrieved from: http://dspace.univbiskra.dz:8080/jspui/bitstream/123456789/8582/1/a6.pdf

[33] Boas, I.V. 2011. Process writing and the internet: Blogs and Ning networks in the classroom. English Teaching Forum, 49(2), 26-33.

[34] Omar, H., Embi, M.A., Yunus, M.M. 2012. ESL learners' interaction in an online discussion via Facebook. Asian Social Science, 8(11), 67-74.

[35] Hussin, S., Abdullah, M.Y., Ismail, N., Yoke, S.K. 2015. The effects of CMC applications on ESL writing anxiety among postgraduate students. Canadian Center of Science and Education, 8(9), 167-172.

[36] Allam, M., Elyas, T. 2016. Perceptions of using social media as an EFL tool among EFL teachers in Saudi context. Canadian Center of Science and Education, 9(7), 1-9.

[37] Tiryakioglu, F., Erzurum, F. 2011. Use of social networks as an education tool. Contemporary Educational Technology, 2(2), 135-150.

[38] Alsulami, S. 2016. The effects of technology on learning English as a foreign language among female EFL students at Effatt College: An exploratory study. Canadian Academy of Oriental and Occidental Culture, 12(4), 1-16.

[39] Lampe, C.A., Ellison, N., Steinfield, C. 2007. A familiar face (book): profile elements as signals in an online social network. In Proceedings of the SIGCHI conference on Human Factors in Computing Systems, 435-444.

[40] Shih, R.C. 2011. Can Web 2.0 technology assist college students in learning English writing? Integrating Facebook and peer assessment with blended learning. Australasian Journal of Educational Technology, 27(5), 829-845 
[41] Maesin, A., Mansor, M., Shafie, L.A. 2009. A study of collaborative learning among Malaysian undergraduates. Asian Social Science, 5(7), 7076.

[42] Foroutan, M., Noordin, N., Hamzah, M. S. 2013. Weblog promotes ESL learners" writing autonomy. Journal of Language Teaching and Research, 4(5), 994-1002.

[43] Krasnova, T., Ananjev, A. 2015. Students' perceptions of learning in the online discussion environment. Mediterranean Journal of Social Sciences, 6(6), 202-207.

[44] Daniel, E. 2017, May 3. Online classes the way forward. New Straits Time.

Retrieved

from:https://www.nst.com.my/education/2017/05/236086/online-

classes-way-forward

[45] Shooshtari, Z.G., Mir, F. 2014. ZPD, tutor; peer scaffolding: Sociocultural theory in writing strategies application. Procedia - Social and Behavioral Sciences, 98(2014), 1771-1776.

[46] Sakkir, G., Rahman, Q., Salija, K. 2016. Students' perception on social media in writing class at STKIP MuhammadiyahRappang, Indonesia. Canadian Center of Science and Education, 6(3), 170-175.

[47] Mbodila, M., Ndele, C., Muhandji, K. 2014. The effect on social media on students' engagement and collaboration in higher education: A case study of the use of Facebook at a South African University. J Communication, 5(2), 115-125.

[48] Majid, A.H., Stapa, S.H., Keong, Y.C. 2015. Blended scaffolding strategies through facebook for learning and improving the writing process and writing performance. Journal of Social Sciences and Humanities, 31-39.

[49] Noriah, I., Intan, S.M.A.A. 2012. An analysis of ESL students' attitude and interest towards learning to write essays using Selected Online Writing Links and Resources. The International Journal of Knowledge, Culture and Change Management, 11(6), 187-198.

[50] Endoo, P. 2015. Facebook implementation in developing English writing for Thai students. Retrieved from: https://arxiv.org/ftp/arxiv/papers/1504/1504.02202.pdf

[51] O'Melia, S. 2011. How can pre writing strategies benefit students. Education Master, 1-53.

[52] Stuyf, R.R. 2002. Scaffolding as a teaching strategy.

[53] Daze, B.D., Ebibi, J.O. 2014. Effect of process approach to writing on senior secondary students' achievement in writing (Plateau Central Senatorial district). International Journal of Arts and Humanities, 3(4), 47 61

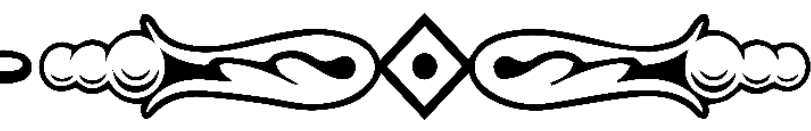

